\title{
A dilatatív cardiomyopathia és a hipokinetikus nem dilatatív cardiomyopathia új definíciója. Az ESC Szívizom- és Pericardium Betegségek Munkacsoport állásfoglalása
}

\author{
Sepp Róbert
}

Szegedi Tudományegyetem, Szent-Györgyi Albert Klinikai Központ, II. sz. Belgyógyászati Klinika és Kardiológiai Központ, Szeged

Levelezési cím: Dr. Sepp Róbert, 6725 Szeged, Semmelweis u 8., e-mail: sepprobert@gmail.com

Az Európai Kardiológus Társaság Szívizom- és Pericardium Betegségek Munkacsoportja a dilatatív cardiomyopathia (DCM) revideált definíciójára tett javaslatot a közelmúltban. Az új állásfoglalás a kórképet egy betegségspektrumként határozza meg, amely a tünetmentes állapottól a DCM típusos megjelenéséig tartó fázist öleli át. A betegség klinikai fázisába a típusos DCM-et, illetve a hipokinetikus nem dilatált cardiomyopathiát (HNDC) sorolja, míg a preklinikai fázisában izolált balkamra-dilatáció, illetve aritmiás CMP lehet jelen.

Az állásfoglalás célja, hogy segítse a DCM-es betegek családtagjaiban észlelt, a betegség potenciális korai manifesztációjának tartható heterogén klinikai megjelenés egységes megítélését, amely korai diagnózishoz és preventív kezelés elindításához vezethet.

Kulcsszavak: dilatatív cardiomyopathia, hipokinetikus nondilatatív cardiomyopathia, genetika

Proposal for a revised definition of dilated cardiomyopathy, hypokinetic non-dilated cardiomyopathy, and its implications for clinical practice: a position statement of the esc working group on myocardial and pericardial diseases In this paper the Working Group on Myocardial and Pericardial Disease of the European Society of Cardiology proposes a revised definition of dilated cardiomyopathy $(\mathrm{DCM})$ in an attempt to bridge the gap between our recent understanding of the disease spectrum and its clinical presentation in relatives, which is key for early diagnosis and the institution of potential preventative measures. They also provide practical hints to identify subsets of the DCM syndrome where aetiology directed management has great clinical relevance.

Keywords: dilated cardiomyopathy, hypokinetic non-dilated cardiomyopathy, genetics

A dilatatív cardiomyopathia (DCM) a bal vagy mindkét kamra tágulatával és csökkent szisztolés funkciójával jellemzett szívizombetegség, amelynek hátterében szekunder ok, mint koronáriabetegség, billentyűbetegség vagy perikardiális betegség kizárható (1). A DCM pontos prevalenciája az átlagpopulációban nem ismert. Az esetek legalább 25\%-ában családi halmozódás mutatható ki, jórészt autoszomális domináns öröklésmenettel. Utóbbi eseteket cytoskeletalis, szarkomer/Z-sáv, nukleáris membrán vagy interkalaris diszkuszt kódoló gének mutációi okozzák, közülük a titin gén érintettsége a leggyakoribb (2). Az X-kromoszómához kötött formákat a dystrophin gén mutációi okozzák, a Becker/
Duchenne-izomdisztrófia klinikai spektrumában jelennek meg. DCM-et mitokondriális és örökletes metabolikus betegségek is létrehozhatnak (pl. haemochromatosis). A DCM nem genetikai okai közül a toxikus eredet (pl. alkohol), illetve kardiotoxikus citosztatikumok következtében kialakult DCM emelhető ki. A DCM myocarditis késői fázisaként is kialakulhat (3). A külön entitásként szerepelő peripartum cardiomyopathia (PPCM) ritka, de potenciálisan életet veszélyeztető kórkép, amelyet a terhesség végén vagy a szülést követő hónapokban kialakuló, ismeretlen eredetű szisztolés diszfunkció jellemez (4). A DCM legfontosabb etiológiai tényezőit az 1. táblázat foglalja össze. 
TÁBLÁZAT. A dilatatív cardiomyopathia etiológiai tényezői

1. Genetikai tényezők

1.1 Föbb DCM-et okozó gének

titin (TTN), lamin A/C (LMNA),

béta miozin nehéz lánc ( $M Y H 7$ ), troponin T (TNNT2), miozin-kötö C-fehérje (MYBPC3), RNA-kötő motif-20 (RBM20), myopalladin (MYPN), Na-csatorna, alfa-alegység (SCN5A), $\mathrm{BaCl}_{2}$-asszociált athanogene 3 (BAG3), phospholamban (PLN)

1.2 Neuromuscularis Duchenne-izomdisztrófia (DMD), betegségek Becker-izomdisztrófia (BMD) Myotoniás disztrófia (MD)

1.3 Szindróma asz- Mitokondriális betegségek szociált betegségek Barth-szindróma (tafazin, TAZ/G4.5)

2. Gyógyszerek, toxikus ágensek

2.1 Antineopláziás anthracyclinek, antimetabolitok, alkiláló szerek ágensek, taxol, hipometiláló ágensek, monoklonális antitestek, tirozin-kináz inhibitorok, immunomoduláló ágensek

2.2 Pszichiátriai szerek

clozapin, olanzapin; chlorpromazin, risperidon, lítium; metilfenidat, triciklikus antidepresszánsok

2.3 Egyéb szerek chloroquin, transz-retinol sav, anti-retrovirális ágensek, fenotiazinok

2.4 Toxikus ágensek alkohol, kokain, amfetaminok, ecstasy, arzén, kobalt, anabolikus/androgén szteroidok, vas (haemochromatosis)

3. Nutricionális tényezők

szelénium-deficiencia (Keshan-betegség), thiamin-deficiencia (beri-beri), cink- és réz-deficiencia, karnitindeficiencia

4. Elektrolit-eltérések

5. Endokrinológiai okok

hypocalcaemia, hypophosphataemia

hypo- és hyperthyreosis, Cushing/ Addison-kór, phaeocromocytoma, acromegalia, diabetes mellitus

6. Infekció

vírusos (pl. HIV), bakteriális

(pl. Lyme-kór), mikobakteriális, gombás, parazitás (Chagas-betegség)

7. Autoimmun eredet

7.1 Szervspecifikus óriás-sejtes myocarditis, inflammatorikus DCM

7.2 Nem szervspecifikus

polymyositis/dermatomyositis, Churg-Strauss-szindróma, Wegenergranulomatosis, SLE, sarcoidosis

8. Peripartum

\section{A dilatatív cardiomyopathia (DCM) diagnosztikus kritériumainak újradefiniálása}

A dilatatív cardiomyopathia (DCM) diagnosztikus kritériumainak újradefiniálása nemrégiben történt meg az Európai Kardiológus Társaság Szívizom- és Pericardium Betegségek Munkacsoportja részéröl (5). Utóbbit az tette szükségessé, hogy az elmúlt évek kutatásai fontos új adatokat szolgáltattak a fenti kórképek etiológiáját és természetes lefolyását illetően. Különösképpen az került felismerésre, hogy számos betegben a kórkép kifejlődését hosszú preklinikai fázis előzi meg, amely nem feltétlenül jár kifejezett tünetekkel és az eszközös vizsgálatokkal észlelhető minor eltérések önmagukban nem tarthatók diagnosztikusnak (6-9).

Bár a DCM korábbi definíciója klinikai szempontból jól használható volt, mára nyilvánvalóvá vált, hogy kiegészítésre szorul. Utóbbit elsősorban az indokolja, hogy a DCM spektruma számos genetikus és szerzett eredetű kórképet fed át (10-12), amelyben az elektromos és funkcionális eltérések jelentős időbeli változatosságot mutatnak. Ez különösképpen a genetikai eredetủ DCM-re igaz, ahol késői megjelenésű vagy inkomplett expresszióval találkozhatunk, számos olyan mutációhordozóval, akik intermedier fenotípust mutatnak, és hagyományos diagnosztikus kritériumok alapján nem diagnosztizálhatók (13-15). Fentiek alapján szükségesnek látszott a DCM klinikai definíciójának kiszélesítése elsősorban DCM-es betegek családtagjaiban és egy új kategória, a hipokinetikus, nem dilatatív cardiomyopathia új kategóriájának bevezetése (hypokinetic non-dilated cardiomyopathy, HNDC).

A DCM klinikai spektrumát az 1. ábra mutatja be. Számos egyénben, mint pl. tünetmentes mutációhordozókban (13-15), vagy akikben szívellenes antitestek mutathatók ki $(6,16)$, egy manifeszt expresszió nélküli preklinikai fázis észlelhető, amelyet enyhe kardiális abnormalitások megjelenése követ. Utóbbiak közé tartozik pl. az izolált balkamra-dilatáció (amely familiáris DCM-es családtagok 25\%-ában mutatható ki, és később DCM-é progrediál) (7) vagy aritmiák (ventrikuláris vagy szupraventrikuláris aritmiák vagy vezetési zavarok), amelyek myocarditis (3) vagy lamin A/C génmutáció-hordozókban (13) figyelhető meg. A kialakult DCM-et szisztolés diszfunkció és balkamra-dilatáció jellemzi, de utóbbi hiányozhat néhány speciális esetben (pl. lamin A/C génmutáció-hordozókban), ami diagnosztikus félreértésekhez vezethet. Utóbbiak miatt tünik indokoltnak a hipokinetikus, nem dilatatív cardiomyopathia (HNDC) új kategóriájának bevezetése.

\section{Az ajánlás által meghatározott definíciók \\ Dilatatív cardiomyopathia}

Bal kamrai vagy biventrikuláris szisztolés diszfunkció és dilatáció, amelyet nem magyaráznak abnormális terhelési viszonyok vagy koronáriabetegség.

\section{Szisztolés diszfunkció}

Kóros ejekciós frakció (LVEF <45\%) két vizsgáló módszerrel, vagy egy módszerrel két különböző időpontban (lehetöleg TTE vagy MRI). Balkamra-tágulat: LVED-volumen vagy LVED-átmérő: >normál +2SD ( $Z$ score >2, www.parameterz.com).

\section{Hipokinetikus nem dilatatív cardiomyopathia (HNDC)}

Bal kamrai vagy biventrikuláris globális szisztolés diszfunkció (LVEF <45\%) dilatáció nélkül, amelyet nem ma- 


\begin{tabular}{|c|c|c|c|c|}
\hline \multicolumn{3}{|c|}{$\begin{array}{c}\text { Preklinikai vagy korai fázis } \\
\text { (DCM-es vagy HNDC-s család tagja) }\end{array}$} & \multicolumn{2}{|c|}{ Klinikai fázis } \\
\hline $\begin{array}{c}\text { Nincs kardiális } \\
\text { megjelenés } \\
\\
\text { (Mutációhordozó } \\
\text { és/vagy } \\
\text { AHA pozitív) } \\
\text { (nincs BK abn, } \\
\text { nincs aritmia) } \\
\left(\mathrm{DCM}_{\mathrm{ND}-\mathrm{NH}, \mathrm{Mut}+\mathrm{AHA}}\right)\end{array}$ & 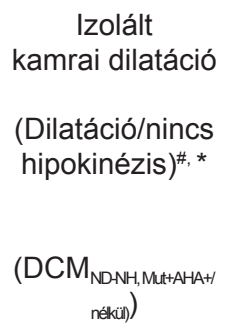 & $\begin{array}{c}\text { Aritmiás CMP } \\
\text { (Aritmiák vagy } \\
\text { átvezetési zavar) }{ }^{\#} \\
\left(\mathrm{DCM}_{\mathrm{ND}-\mathrm{NH}-\mathrm{A} / \mathrm{CD},}\right. \\
\text { Mut+AHA+/né|kül) }\end{array}$ & $\begin{array}{l}\text { Hipokinetikus nem dilatatív } \\
\text { CMP } \\
\text { (Hipokinézis/nincs dilatáció) } \\
\left.\text { (HNDC vagy } \mathrm{DCM}_{\mathrm{ND}-\mathrm{H}}\right)\end{array}$ & $\begin{array}{c}\text { Dilatatív CMP } \\
\text { (BK dilatáció+hipokinézis) } \\
\left(\mathrm{DCM}_{\mathrm{ND}-\mathrm{H}}\right)\end{array}$ \\
\hline & & & \multicolumn{2}{|c|}{ Fenotípus progresszív kifejeződése } \\
\hline
\end{tabular}

1. ÁBRA. A DCM klinikai spektruma. DCM: dilatatív cardiomyopathia, AHA: anti heart antibody, A: aritmia, DC: vezetési zavar, ND: nem dilatált, NH: nem hipokinetikus, D: dilatált, H: hipokinetikus, HNDC: hipokinetikus, nem dilatált cardiomyopathia. (Forrás: Pinto YM, Elliott PM, Arbustini E, et al. Proposal for a revised definition of dilated cardiomyopathy, hypokinetic non-dilated cardiomyopathy, and its implications for clinical practice: a position statement of the ESC Working Group on Myocardial and Pericardial Diseases. European Heart Journal 2016; 37, 1850-1858.)

gyaráznak abnormális terhelési viszonyok vagy koronáriabetegség.

A hozzátartozók esetében major és minor diagnosztikus kritériumokat határoz meg (2. táblázat). Fenti kritériumok alapján definitív, valószínủ és lehetséges betegség kategóriákat különít el.

\section{TÁBLÁZAT. Major és minor diagnosztikus kritériumok hozzátartozókban}

I. Major kritérium

1. A BKEF mással nem magyarázható csökkenése $(\leq 50 \%$, de $>45 \%$ ); VAGY

2. Mással nem magyarázható BKED-dilatáció (átmérő vagy volumen) nomogram alapján (LVED-átmérö/volumen: $>2 \mathrm{SD}+5 \%)$

II. Minor kritérium

1. Komplett LBBB, vagy AV-blokk (PR: >200 ms vagy magas fokú AV-blokk)

2. Mással nem magyarázható kamrai aritmia (>100 kamrai ES/óra 24 óra alatt vagy nem tartós VT, $\geq 3$ ütés $\geq 120 / m i n$ frekvenciával);

3. Szegmentális BK-falmozgászavar intraventricularis vezetési zavar hiányában

4. Nem iszkémiás eredetủ késői kontrasztanyag-halmozás MRI-n

5. Nem iszkémiás eredetű miokardiális abnormalitások (gyulladás, nekrózis és/vagy fibrosis) szívizom-biopszia kórszövettani vizsgálata alapján

6. Szervspecifikus vagy betegségspecifikus szívellenes-antitestek jelenléte

\section{Definitiv betegség}

- A DCM vagy HNDC diagnosztikus kritériumai teljesülnek.

\section{Valószínúi betegség (2. ábra)}

- egy major kritérium és legalább egy minor kritérium megléte, VAGY

- egy major kritérium megléte olyan betegekben akik az indexbetegben azonosított génmutációt hordozzák.

\section{Lehetséges betegség (3. ábra)}

- két minor kritérium megléte, VAGY

- egy minor kritérium megléte olyan betegekben, akik az indexbetegben azonosított génmutációt hordozzák, VAGY

- egy major kritérium megléte minor kritérium nélkül olyan betegekben, akikben a genetikai háttér nem ismert.

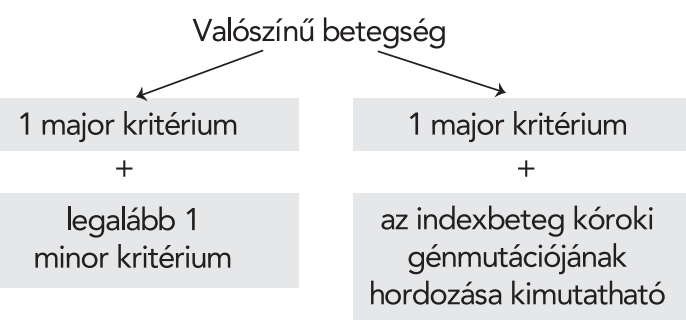

2. ÁBRA. A dilatatív cardiomyopathia valószínű fennálltának diagnosztikus kritériumai a preklinikai szakban az indexbeteg hozzátartozóiban. A major és minor kritériumokat ld. a 2. táblázatban 


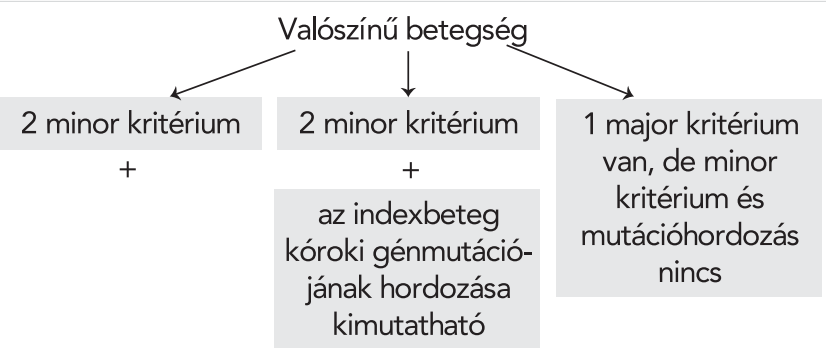

3. ÁBRA. A dilatatív cardiomyopathia lehetséges fennálltának diagnosztikus kritériumai a preklinikai szakban az indexbeteg hozzátartozóiban. A major és minor kritériumokat ld. a 2. táblázatban

\section{Familiáris betegség}

Az állásfoglalás a családtagok vizsgálata alapján a familiáris betegséget is definiálja (amennyiben nincs konkluzív genetikai diagnózis), amely szerint familiáris betegségről beszélünk akkor, ha:

- két vagy több családtagban (első vagy másodfokú rokonok) kimutatott definitív DCM vagy HNDC áll fenn;

- DCM/HNDC-vel diagnosztizált indexbeteg, és egy autopsziával igazolt és 50 év alatti hirtelen szívhalál található elsőági rokonban.

A kivizsgálás menetére a következő javaslatokat teszi:

1. Szignifikáns koronáriabetegség kizárandó 35 éves életkor felett, vagy amennyiben 35 éves életkor alatt szignifikáns ISZB-rizikófaktorok vannak vagy a családban korai koronária-betegség fordult elö.

2. Első vonalbeli laboratóriumi vizsgálatok: CK, vesefunkció, proteinuria, májfunkció, Hgb és Fvs, se vas és ferritin, kalcium, foszfát, BNP/NTpBNP, TSH.

3. Másodvonalbeli vizsgálatok a feltételezett oki tényezőt kell, hogy célozzák.

4. Szív MRI a szívmorfológia és funkció, valamint a szöveti tipizálás megítélésében lehet hasznos.

5. Klinikailag feltételezett myocarditis esetén endomyocardialis biopszia (szövettani, immunohisztológiai és az esetleges fertőző ágens azonosítása PCR-rel) javasolt. Biopszia tárolási vagy metabolikus betegségek klinikai gyanúja esetén is szóba jön, amennyiben más módszerekkel a diagnózis nem biztosítható.

6. A familiáris anamnézistöl függetlenül a DCM-es betegek elsőági hozzátartozóinak kardiológiai szürése javasolt (EKG és echokardiográfia).

7. Genetikai szúrés javasolt familiáris halmozódású DCM esetén vagy azon sporadikus DCM-esetekben, ahol a klinikai tünetek specifikus etiológiára utalnak (pl. AV-blokk vagy CK-emelkedés).

8. A genetikai teszt az esetlegesen fennálló specifikus etiológia megerősítésére kell, hogy irányuljon és ismerten DCM-et okozó gének vizsgálatára kell, hogy szorítkozzon. Nagy génpaneleket vizsgáló újgenerációs szekvenálás abban az esetben javasolt, ha szegregációs analízisre alkalmas családfa van jelen (több érintett DCM-es családtag).
Kardiológiai szűrővizsgálat az indexbeteg valamennyi elsőfokú rokonánál javasolt, függetlenül a családi kórtörténettől. A vizsgálatokat 2-3 évenként ismételni kell, évente, ha minor eltérések vannak. A biopsziával igazolt gyulladásos DCM-s indexegyén tünetmentes hozzátartozóinál szívellenes-antitestek levétele szükséges alaphelyzetben és az utánkövetésnél. A kardiológiai ellenőrzés gyakrabban kell, hogy történjen, amennyiben szívellenes-antitest mutatható ki a családtagban.

\section{Következtetések}

Összefoglalva, az új állásfoglalás a DCM-et egy betegségspektrumként határozza meg, amely a tünetmentes állapottól a DCM típusos megjelenéséig tartó fázist öleli át. A betegség klinikai fázisába a típusos DCM-et, illetve a hipokinetikus nem-dilatált cardiomyopathiát (HNDC) sorolja, míg a preklinikai fázisában izolált balkamra-dilatáció, illetve aritmiás CMP lehet jelen. Fenti megközelítés hozzájárulhat ahhoz, hogy segítse a DCM-es betegek családtagjaiban észlelt, a betegség potenciális korai manifesztációjának tartható heterogén klinikai megjelenés egységes megítélését, amely korai diagnózishoz és preventív kezelés elindításához vezethet.

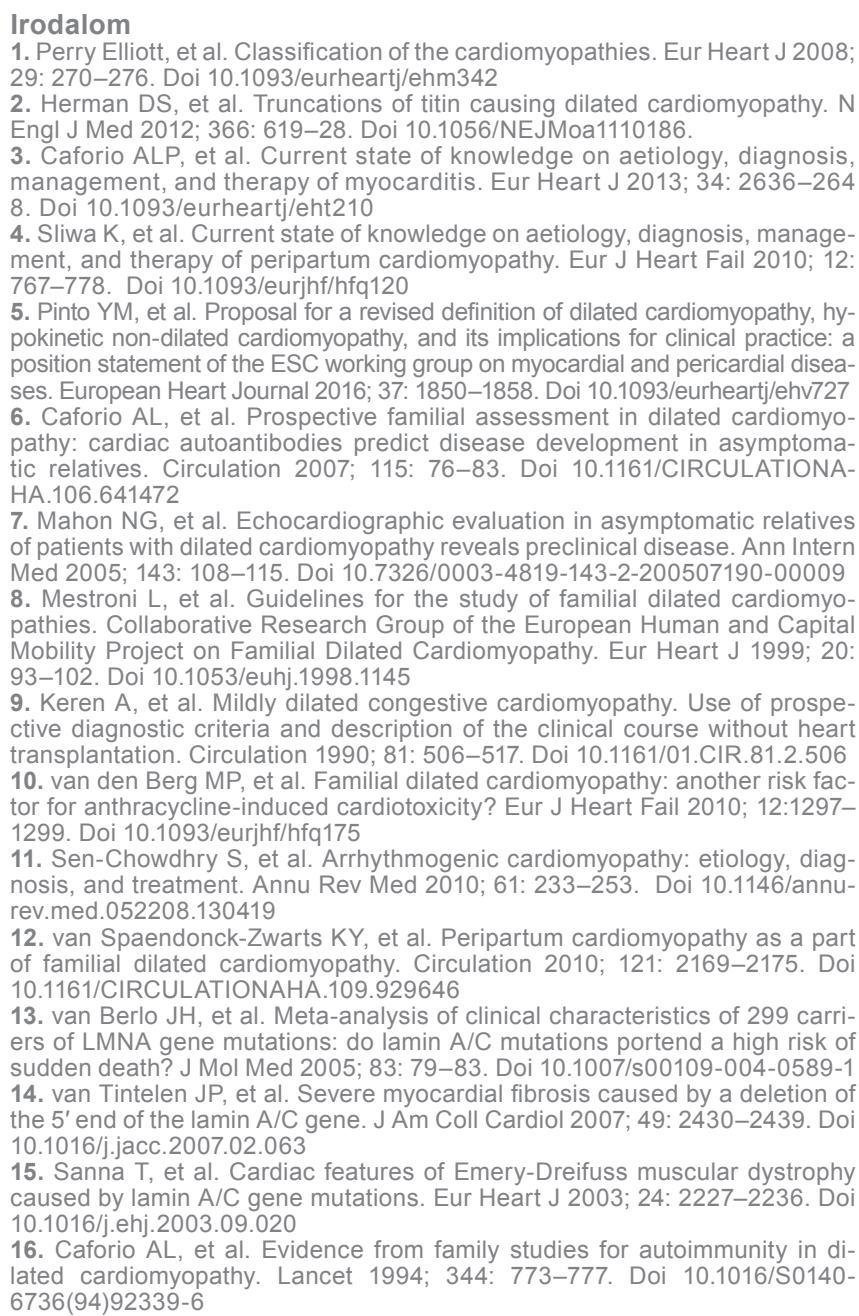

